\title{
Islamists and the state: changing discourses on the state, civil society and democracy in Turkey
}

\section{Talha Köseoğlu}

To cite this article: Talha Köseoğlu (2018): Islamists and the state: changing discourses on the state, civil society and democracy in Turkey, Turkish Studies, DOI: 10.1080/14683849.2018.1521281

To link to this article: https://doi.org/10.1080/14683849.2018.1521281

曲 Published online: 13 Sep 2018.

Submit your article to this journal

Џll Article views: 171

View Crossmark data \lceil 


\title{
Islamists and the state: changing discourses on the state, civil society and democracy in Turkey
}

\section{Talha Köseoğlu}

Faculty of Economic, Administrative and Social Sciences, Department of Political Science and Public Administration, Bilkent University, Ankara, Turkey

\begin{abstract}
Once an oppositional ideology in the 1990s that united Muslim intellectuals around a radical critique of the state based on the ideals of democracy, civil society and pluralism, how has Turkish Islamism transformed into a statecentric and conservative world-view? This paper aims to document this transformation by scrutinizing the writings of a group of intellectuals in the context of (I) the 28 February 1997, military memorandum and the subsequent events which culminated in the AKP's first electoral victory in 2002; and (II) the series of trials that started in 2008 known as the Ergenekon trials through which the AKP gained the upper hand in Turkish politics. In so doing, the paper problematizes the prevalent narratives on the relationship between Islam, on the one hand, and democracy and civil society, on the other, that miss how formulations and articulations of Islamism evolve in changing political contexts.
\end{abstract}

ARTICLE HISTORY Received 21 December 2017; Accepted 2 August 2018

KEYWORDS Muslim intellectuals; Yeni Zemin; Turkish politics; civil society; Islamism; AKP

\section{Introduction}

As infringements against the separation of powers, restrictions on freedom of expression and draconian suppression of any protest movement have become common occurrences in Turkey, Turkish Islamism's democratic and pluralist turn with the ruling Justice and Development Party (Adalet ve Kalkinma Partisi, AKP) seems to be in the remote past. Recent studies are already revising earlier accounts to explain why the AKP has diverged from its former discourse promoting the enlargement of democratic rights and liberties, European Union (EU) membership and integration into the global capitalist system. However, why this transformation has not undermined the party's legitimacy among Muslim intellectuals who had advocated for democracy

CONTACT Talha Köseoğlu talha.koseoglu@bilkent.edu.tr $\Theta$ Faculty of Economic, Administrative and Social Sciences, Department of Political Science and Public Administration, Bilkent University, Bilkent, Ankara 06800, Turkey

(c) 2018 Informa UK Limited, trading as Taylor \& Francis Group 
and civil society in the 1990 s and early 2000s remains a serious academic puzzle. Once an oppositional ideology that united many Muslim intellectuals around a radical critique of the state based on the ideals of democracy, civil society and pluralism, how has Turkish Islamism transformed into a statecentric and conservative world-view? This paper aims to document this transformation in Islamist political thought in Turkey since the 1990s. In so doing, it problematizes the prevalent narratives on the relationship between Islam, on the one hand, and democracy and civil society, on the other, that miss how formulations and articulations of Islamism evolve in changing political contexts.

The alternative reading of Turkish Islamism I offer in this paper aims to explain its transformation in the context of two major political processes in the recent history of Turkey. The first started with the 28 February 1997, military memorandum and culminated in the AKP's first electoral victory in 2002. The second can be stretched back to the series of trials that started in 2008 known as the Ergenekon trials, continued with the 2010 Constitutional referendum and the AKP's third electoral victory in 2011. Through this process the AKP gained the upper hand in Turkish politics as large number of Kemalist military and bureaucratic elite were removed from positions of power. Evaluating the writings of a group of influential and prolific Muslim intellectuals regarding these major political events and processes, I argue that Islamism in Turkey should not be seen as a unified ideology proper but as an ensemble of discourses that constantly mutates and reconstitutes itself depending largely on the position of the Islamic segments of society vis-à-vis the political system. In so doing, I show, on the one hand, how different Islamists employ, stress and/or redefine a broad vista of political concepts, principles and ideals in different ways for different purposes; and on the other, the extent to which traces of the AKP's authoritarian turn in the 2010s can be found in Muslim intellectuals' debates on democracy and civil society in the 1990s and 2000s.

In what follows, I will first discuss studies which conceptualized the Islamist discourse on state, civil society and democracy, and offer an alternative approach to analyze and understand Turkish Islamism's journey since the 1990s. Then, I will introduce the intellectual circle through which I construct my argument in this paper and situate their ideological stance in the 1990s in the larger Turkish context. The subsequent empirical sections will highlight Muslim intellectuals' definitions of the state, their vision of state-society-individual relations and discussions on civil society and democracy. First, I will analyze intellectuals' 1990s critique of Turkey's state establishment through post-Cold War discourses of liberalism and democracy. The following section will trace trajectories of the same intellectuals following the events of 28 February 1997, by laying out the impact of the military intervention on Islamist political thought. This section will extensively discuss Islamist 
discourse within the context of 'Islamist moderation' and compare this discourse with that of the newly founded AKP. The last section will delineate the discursive shifts in the writings of Muslim intellectuals after 2008 as the AKP took root in the state establishment and integrated Islamic segments of society into the existing socio-political system.

\section{Conceptualizing Islamist transformation}

Islamist discourse on democracy and civil society has attracted scholars' attention ever since Islamists in the Middle East were drawn to the notion of civil society in the immediate aftermath of the Cold War. In the early 1990s, the notion that Islam did not need the state or political power in order to exist as a religion that shapes the social life of Muslims started to seep into debates among Muslim intellectuals. This transformation from an emphasis on the necessity of founding a Sharia-based state to a quest to establish Islamic hegemony over civil society has been understood and explained differently by scholars. ${ }^{1}$ Accompanying the conceptualizations of ideological change was the growing literature on Islamist moderation which mainly focuses on the behavior of Islamist political parties. The moderation thesis suggests that under the threat of political systems which endanger the survival of their organizations and in pursuit of vote-maximization, Islamist radicals agree to the terms of participation in democratic politics by gradually dropping their radical positions. ${ }^{2}$ Both bodies of literature considered new, more democratically-oriented Islamist discourse as a viable alternative to authoritarian regimes in the Middle East as the (moderated) Islamist discourse had a potential to promote pluralism and consolidate democracy. ${ }^{3}$

Drawing on similar assumptions, most studies explained the emergence of the AKP as a result of 'moderation' in Islamism in the 1990s through Islamists' acquiescence to the ideals of democracy, civil society and pluralism. ${ }^{4}$ The AKP's emphasis on economic stability and growth as well as its democratic reform agenda in line with the EU process was seen to be a success story in Islamist moderation and hailed as a model for other Muslim-majority countries in the region. This trend crested in the wake of the Arab Spring whereby Islamist groups and parties were preached to emulate the liberal Muslim democracy in Turkey. ${ }^{5}$ Neither the moderation literature nor those who have expected consolidation of democracy as a result of Islamists' turn to civil society could envision the almost simultaneous failure of the Arab Spring, especially in Egypt, Libya and Syria, and the increasing authoritarianism in Turkey under AKP rule.

The main source of confusion lies in disagreement on the content of the term 'moderation' and whether different meanings attributed to moderation are capable of characterizing the intellectual transformation in Islamist discourse. The formulation of the main thesis of moderation theory, i.e. 
acquiescence of non-confrontational Islamist parties to the regimes to the extent that regimes tolerate them, implies that moderation involves, if not amounts to, accommodation. Defined as such, moderation is merely a political strategy, whether the principles of democratic participation it entails are internalized or not. Despite its prevalence among many of the proponents of the moderation theory and its critics alike, this is not the only conceptualization of moderation. Shadi Hamid distinguishes the term from both pragmatism and non-confrontation, and identifies moderation with Islamists' 'approach to democracy and the democratic process and, relatedly, the primacy of Islamic law in the political order; cooperation with non-Islamist groups; their positions and policies toward women's and minority rights; and degree of internal organizational reform. ${ }^{6}$ As such, Hamid defines moderation as an ideological change toward commitment to democratic principles and values.

In contrast to Hamid, Asef Bayat suggests that the shift from a worldview centered on the ideal of an Islamic state to a worldview that respects political pluralism and democratic rights represents the emergence of 'post-Islamism,' rather than moderation. Characterizing this shift as a 'qualitative change' Bayat argues that 'the term [moderation] would be unable to ascertain the dynamics and direction of change ... [as] it signifies the degree (rather than the kind) of departure from "radicalism"." In this sense, moderation and post-Islamization are two different processes that may operate independently in different settings, though any coincidence of the two is possible. Similarly, I treat moderation as an attitude within a political system, instead of a committed ideological position. The historical reading of contemporary Turkish Islamism in this paper will explore the entangled processes of post-Islamization and Islamist moderation in the Turkish context which has the potential to offer insights into Islamist transformation in the Middle East and Islamists' failure to consolidate democracy in the region.

It is my contention that the inadequacy of existing accounts in explaining Islamic movements in general and Islamism in Turkey in particular stems from a lack of solid premises with regard to the intellectual aspect of Islamism. Studies usually overlook the dynamics of Islamists' debates on the state, civil society and democracy due mainly to their narrow focus on political actors and their inattentiveness to Muslim intellectuals' shifting discourses in different contexts. Analyzing the writings of Muslim intellectuals in an attempt to map out Islamist political thought in Turkey and to understand Islamist transformation is an emerging approach with very few examples. Among others, Michelangelo Guida's work has compared the interpretations of democracy by two leading Muslim intellectuals in Turkey, ${ }^{8}$ and Yüksel Taşkın analyzes the articulation of the concept of 'conservative democracy' by authors of pro-AKP newspapers. ${ }^{9}$ Despite their valuable contributions to our understanding of Islamist political thought in Turkey, with their 
limited scope, these studies do not shed light on the diversity within Turkish Islamism and its variations in time. ${ }^{10}$

In a very recent article, Halil İbrahim Yenigün offers a conceptual framework to account for the variations in Turkish Islamism. Yenigün distinguishes the quest for promoting the interests of Muslims from the political project of Islamism which, for Yenigün, refers to establishing a polity based on Islamic principles, most notably justice. Defining the former attitude as 'Muslimism,' Yenigün argues that this analytical distinction between Muslimism and Islamism enables us to grasp the authoritarian turn of the AKP as time proved the prevalence of a Muslimist attitude among AKP cadres and ideologues. ${ }^{11}$ This paper draws on a similar conceptual framework in evaluating the writings of Muslim intellectuals in Turkey from the 1990s onwards. It aims to delineate the extent to which the position of the Islamic segments of society vis-à-vis the political system explain the Islamist political thought in the 1990s and its transformation during the AKP era.

The term 'Islamic segments' is frequently used in the literature to refer to different constituencies of the Islamic movement and religious conservative groups and individuals. ${ }^{12}$ I argue that the diversity among Turkish Islamism and its variations over time depends largely on the socio-political position of the Islamic segments of society and the degree of Muslim intellectuals' attachment to this imagined Muslim community. ${ }^{13}$ Hence, the empirical portions of this paper discuss variations in Islamist discourse on the state, civil society and democracy by documenting different articulations of these concepts by Muslim intellectuals vis-à-vis the major events that shaped the political landscape in Turkey and altered the conditions for its Islamic segments. To this end, I analyze a group of highly influential and prolific Muslim intellectuals who, despite differences in their approaches to democracy and civil society, had gathered under the umbrella of Yeni Zemin (New Ground), an Islamist political magazine, in 1993 to enunciate the Islamist critique of the state and later went on very disparate individual trajectories.

\section{Yeni Zemin in context}

Publishing only 17 issues during its run from 1993 to 1994, ${ }^{14}$ Yeni Zemin might not be the most popular Islamist magazine of the 1990s, and it is infrequently remembered today even within Islamist circles. However, I decided to focus on Yeni Zemin both for its unique cluster of intellectuals, which is remarkable for a single magazine in terms of diversity and influence, and for its rich content which, in each issue, dealt extensively with crucial contemporaneous problems. The magazine was owned by Osman Tunç, who was a manager of Zehra Vakf1, a Nurcu foundation espousing a Kurdish-Islamic identity. ${ }^{15}$ Mehmet Metiner, known for his attempts at a reconciliation of liberal democracy and Islam in the 1990s, was the editor of the magazine. ${ }^{16}$ 
Metiner's assistant was Yalçın Akdoğan, who later became the chief advisor of Recep Tayyip Erdoğan and served as the deputy prime minister between 2014 and 2016. Among the prominent contributors of the magazine were Ali Bulaç, Abdurrahman Dilipak, Davut Dursun, Ergün Yıldırım, Altan Tan, Rasim Özdenören, Atasoy Müftüoğlu, Abdurrahman Arslan, Ümit Aktaş, Cihan Aktaş, Kadir Canatan, İhsan Süreyya Sırma, Mustafa Kamalak, Hüseyin Hatemi and Kenan Çamurcu. Most of these intellectuals also contributed to other Islamist magazines in the 1990s such as İslam Dergisi (1983-1999), Bilgi ve Hikmet (1993-1995), İzlenim (1992-1996) and Değişim (1993-1998).

Yeni Zemin is distinguished among its counterparts foremost by its cover subjects which arguably reflected Islamists' ambition in the 1990s to rule Turkey. 'What Kind of a Constitution?', 'Is Democracy the Last Stage?', 'Is Privatization the Solution?', 'Autonomous Local Governments', 'Kurds: Orphans of the Ummah' are the headlines of five of the seventeen issues, each of which touched upon crucial problems of Turkey. Contributors to the magazine actively engaged with these highly topical issues and offered their practical suggestions. Among other topics, the Kurdish question is given special weight in the magazine for it was financed by a Kurdish-Islamist foundation and run by Metiner, a Kurd from Adiyaman province. Yet, there is another distinctive feature of Yeni Zemin, as the editorial line of the magazine enunciated its demands for democratization, political pluralism and decentralization with the same valor as its coverage of the Kurdish question. Yeni Zemin also presented the inner conflicts of Turkish Islamism regarding Muslims' relationship with democracy and liberalism with the contributions of the intellectuals who remained suspicious of Muslims' acquiescence to liberal democratic concepts and values. Better still, Yeni Zemin was not only a magazine in which Muslim intellectuals articulated their ideas but also a platform of intellectual exchange between Islamists on the one hand, and liberals and conservatives such as Mehmet Altan, Nilüfer Göle, and Ali Yaşar Sarıbay, on the other. ${ }^{17}$

From among the diverse body of intellectuals who wrote in Yeni Zemin, I choose to focus on the most prolific and frequent contributors of the magazine who I believe also represent the diversity of Turkish Islamism with their different backgrounds, political attitudes and trajectories to date. These intellectuals are Mehmet Metiner, Ali Bulaç, Altan Tan, Ümit Aktaş, Davut Dursun, Yalçın Akdoğan, Rasim Özdenören and Abdurrahman Dilipak. Metiner and Akdoğan are members of the AKP; while Akdoğan is still in the parliament, Metiner, after serving as MP since 2011, was not nominated by his party in the 2018 elections. Davut Dursun served as the president of Radio and Television Supreme Council (Radyo ve Televizyon Üst Kurulu [RTÜK]) between 2009 and 2015 and later returned to his academic career as a professor of political science at Sakarya University. Rasim Özdenören and Abdurrahman Dilipak are columnists in dailies Yeni Şafak and Yeni 
Akit, respectively, that are very close to the AKP government. On the other hand, Altan Tan was an MP from the ranks of People's Democratic Party (Halklarm Demokratik Partisi, HDP), a pro-Kurdish opposition party whose discourse strikingly contrasts with that of the AKP, between 2011 and 2018. ${ }^{18}$ Ali Bulaç was a columnist in the daily Zaman and imprisoned for his alleged affiliation to the Gülen network after July 2016 failed coup attempt. ${ }^{19}$ Finally, Ümit Aktaş is a prominent Muslim intellectual who maintains his distance with the AKP and occasionally writes critical pieces against the party in several media outlets including the left-wing Birikim. Thus, in retrospect, the analysis of the magazine and the writings of its most prolific authors through the February 28 process and the AKP's consolidation of power promises us to discover the trajectory of Turkish Islamism.

\section{Yeni Zemin: an Islamist challenge to the state}

In the context of the 1990s, Yeni Zemin was part of a general trend within Islamist political thought of reorienting from a state-centric worldview to a new discourse focusing on civil society. Coming from the Islamists, this departure was striking. With the exception of the liberal left, thorough critiques of the state in intellectual milieus - especially among the ideologies of the political right - were rare in Turkey. The state had been considered almost sacred by both nationalist right and religious conservatives. ${ }^{20}$ They might criticize the Kemalist state establishment for its secularist nature; yet, Islamists in Turkey, not unlike their secular counterparts, saw the state's existence and its ruling mechanisms as legitimate ipso facto. ${ }^{21}$ Thus, before the 1980s, the Islamist attitude towards the state in Turkey did not present any genuine and effective debate on the theory of state, or of authority and power.

In this light, the openly critical attitude in Yeni Zemin towards the state in the 1990s indicates a significant shift in Islamist concept of the state. As stated, the Islamist critique of the state in the 1990s that appeared in Yeni Zemin was both a part of the general trend within the Muslim world, found in various literature informed by the ideas of prominent 'post-Islamist' thinkers such as Mohammed Abed Al-Jabiri, Abdolkarim Souroush and Abdelwahab elAffendi. ${ }^{22}$ More importantly, Islamists in Turkey found vital support in their challenge to the state from among influential members of the liberal intelligentsia, known as ikinci cumhuriyetçiler, ${ }^{23}$ and leftist liberals. The critique of the Kemalist foundations of the Republic and the existing political structure of Turkey by these liberal intellectuals bolstered the legitimacy of the Islamist challenge and provided important intellectual resources for Muslim intellectuals. ${ }^{24}$ While the growing challenges of political Islam and the Kurdish resurgence as well as the end of the Cold War and neoliberal globalization further consolidated the post-Kemalist paradigm, Muslim intellectuals around Yeni Zemin constantly brought up these domestic and 
international political issues as the harbingers of a change in the Kemalist political system in Turkey.

The editorial line of Yeni Zemin called for a wholesale change in the political system that reflected the authors' distaste of laicism and the notion of the modern nation-state, which were viewed as the ideological pillars of Kemalism. Influenced by post-Kemalist ideas and the liberal rhetoric of post-Cold War era, Muslim intellectuals in Yeni Zemin stressed the necessity of democratization, of a pluralist socio-political system, and of the state's retreat from the domain of civil society. These three concepts, civil society, democracy and pluralism, became the most recurrent ones in their critique of the state. Nevertheless, all these concepts were employed or discussed in particular ways to reflect Islamist ideals and aspirations.

Authors in Yeni Zemin challenged the state first by problematizing its 'idolization' by Islamic segments of society. Almost all the authors persistently reminded their readers that attributing sacredness to the state had been a recurring mistake in Islamic societies throughout history. ${ }^{25}$ According to Davut Dursun, the military-bureaucratic elite of the late Ottoman Empire had reconfigured this tradition by synthesizing it with the notion of the 'modern state.' The Republic had been founded by the Kemalist elite upon a 'relentless statism,' and 'therefore, ... the state considered it necessary to organize [even] the way people breathe. ${ }^{, 26}$ Dursun associated the transcendental and paternalistic conception of the state with Kemalist modernization. In so doing, he and like-minded authors addressed primarily religious, conservative people as well as the Welfare Party (Refah Partisi, RP), ${ }^{27}$ which Yeni Zemin did not refrain from criticizing for its allegedly conservative and state-centric political attitude. ${ }^{28}$ In order to desanctify the state and to convince Islamic segments to drop their state-centric conservatism, authors instrumentalized the strong anti-Kemalist sentiments prevalent among these social groups.

The definitions of the state in Yeni Zemin invoked liberal theories of a minimum state in order to further emphasize the view that the state is not sacred. A common way of defining the state was to put forth that it is only an instrument - better yet, a necessary evil - for the good of individuals. The shared conception of the state in Yeni Zemin emphasized the primacy of individual and society over the state. Abdurrahman Dilipak noted that,

[t] he state is the political, military, economic and legal structure constituted by the people living in a certain territory who want to protect and improve their rights; to secure their lives, properties and religious liberties; and to carry out tasks that they are incapable of accomplishing, individually or communally. By this definition, the basis of state's existence and legitimacy is to protect the fundamental human rights and liberties. ${ }^{29}$

Accordingly, the raison d'etre of the state was to secure the good of individuals and society. As such, the state was only a means to the common good and 
bore no sacred or religious role. Interestingly, instead of drawing solely on Islamic sources, this particular conception of the state embraced the idea of the social contract, a core component of Western liberal thought.

Thus, in addition to desanctifying the state, once again Yeni Zemin authors advanced arguments that bear affinities with strands of liberalism in advocating for a minimal state, whose responsibility was limited to the provision of public goods. The state, according to the editorial line, had to be shrunk in order to make room for a larger and autonomous civil society which was defined in opposition to the state. For instance, addressing the need to reevaluate the state's approach to religious affairs, the first article of Yeni Zemin's second issue stated that

the state has to keep its hands off religion and religion has to be autonomous. For this, the DİB [Diyanet Isşleri Başkanlığı (the Directorate of Religious Affairs)] should be gradually abolished; the state must stop TV shows about the faith and give up religious education in schools. In addition, mosques and pious endowments [vakıflar] must be free [of state control]; religious groups and communities must be allowed to operate freely. Let the people establish schools, build hospitals and appoint their own imams to their own mosques. In short, the religious services must be left to civil society. ${ }^{30}$

The passage reflects both the particular grievance among Yeni Zemin authors that the state's intervention into the sphere of religion aroused and the stark antagonism between state and civil society in their discourse.

First, the call for the abolition of the DİB is a major example of the authors' distaste with the state-sponsored Islam in the magazine. Being financed by a Kurdish-Islamist Nurcu foundation, the editorial line of the magazine strictly opposed the state's attempt to restore the legitimacy of Turkish nation-state in the face of the challenges by Islamic movements and Kurdish resurgence through the so-called Turkish-Islamic Synthesis (TIS) project. ${ }^{31}$ Yet, the pro-Kurdish stance of the editorial line alone does not explain all the reactions to the TIS in the magazine. Authors such as Aktaş, Dilipak, Bulaç and Tan in their several writings warned the reader against the state's effort to promote 'moderate $[\imath \mathrm{llm} l \mathrm{l}]$ Islam' in line with American interests in the Middle East to counter Islamist demands for a wholesale change in the political system they called for in Yeni Zemin.

Second, the overall discourse in the magazine rested on an outright contradiction between state and civil society where religion was designated in the civil societal domain. Yeni Zemin authors envisioned the political structure of Turkey in the form of a duality between Kemalist political elite and Muslim people. According to Augustus Norton, contrary to liberal notion of civil society which sees state as the major guarantor of citizenship rights, Islamists had an antagonistic conception of the relationship between the state and civil society where the state must be subordinate to society. ${ }^{32}$ In their calls for a larger civil society, many Muslim intellectuals assumed and/ 
or represented society in Turkey as homogeneously Muslim. Designation of religion within the realm of civil society was an important discursive tool in the Islamist critique of the state. The latter, in contradistinction to the assumed Muslim identity of society, was in the hands of a group of Kemalists who were estranged from the values of the popular masses. ${ }^{33}$

Although the critique of the state was shared by almost all the authors of Yeni Zemin, some authors disagreed with the liberal democratic rhetoric that often presented and justified this critique. The division among the authors manifested itself most clearly in proposed solutions to the tension between state and civil society. On the one hand, most of Yeni Zemin authors such as Mehmet Metiner, Altan Tan, Davut Dursun, Abdurrahman Dilipak and Ümit Aktaş frequently postulated democratizing the political system as the way to alleviate the supposed rift between civil society and the state establishment. However, this pro-democratic stance in the magazine received negative reactions from both other Islamist circles outside the magazine, ${ }^{34}$ and magazine's authors such as Ali Bulaç and Rasim Özdenören. These authors mainly contended that the quest for consolidating a democratic regime in Turkey is an invalid effort for two reasons: Islam already offers the basic governmental principles, hence there is no need to 'speak in others' (read non-Islamic) language'; and democracy is an historical product of secularization and the revolt against the Church in the West which is not compatible with the dynamics of Islamic societies. ${ }^{35}$

In the face of these criticisms, the editorial line as well as other pro-democracy authors sometimes took a defensive and apologetic stance. Authors having positive attitudes towards democracy dissociated it from some of the values attached to it in their responses to the critiques of democracy. They often problematized the assumed link between laicism and democracy and argued that laicism is not a prerequisite for democracy. Pro-democratic authors shared a notion of democracy in which the decision-making process was in line with the cultural, moral and religious values of the people. As such, democracy appeared in Yeni Zemin authors' discourse to be a regime in which 'authentic representation' of the people is reflected onto the political will. ${ }^{36}$ Thus, democracy would resolve the discrepancy between people and the state establishment in Turkey. However, the existing political system, according to Ergün Yıldırım, neither conformed to the values of people in Turkey nor did it allow for political participation. Yıldirım stated that

democracy was hampered by the dominant political apparatuses due to the perception that it would lead to reactionary movements [irticaya yol açacağından] since its real implementation would mean the assertion of the social identity onto political will [toplumun kendini kimliğiyle siyasal iradeye yansıması]. ${ }^{37}$

His remarks imply that in order to secure laicism, the political system prevented full political participation of the people of Turkey, who supposedly 
have a strong Islamic identity. For Ylldırım, laicism was not a pre-requisite of democracy. On the contrary, it was an obstacle for a properly functioning democratic system.

Thus, while the Islamist challenge to the state establishment relied heavily on liberal democratic notions such as civil society and pluralism, some redefined these notions in particular ways to stress mainly the benefits of the Islamic segments of society. ${ }^{38}$ As some of the authors in Yeni Zemin expressed from time to time, the expectation from the consolidation of democracy and the enlargement of civil society is to bring along a 'rapprochement between the state and the people.' The parallels between the way the notions of civil society and democracy were discussed among Yeni Zemin authors and the AKP's authoritarian and majoritarian discourse are obvious. Characterization of society with Muslimness and definitions of democracy as political representation of Muslim identity foreshadow the AKP's recent discourse. Without paying attention to the way Islamists received and reflected the ideals of civil society and democracy, most of the studies reviewed earlier in this paper remain inadequate in understanding the later transformation of Islamist discourse.

\section{Moderation in the critique? The aftermath of February 28}

Although Yeni Zemin's last issue was published in June 1994, the intellectuals who had contributed to the magazine continued writing pieces similarly critical of the political system in different media outlets. ${ }^{39}$ However, the period after the 1997 military intervention brought about important changes in the articulation of the Islamist critique. Following the meeting of the National Security Council on 28 February 1997, where the military issued a memorandum recommending measures against the activities of Islamic organizations and communities to the coalition government led by the Islamically-oriented $\mathrm{RP}$, a process of persecution against the Islamic segments of society started. This included the shutting down of the RP and its successor, the Virtue Party (Fazilet Partisi, FP), the trials of former RP politicians as well as other measures against headscarf, religious secondary schools known as Imam-Hatip, and Qur'an seminaries. ${ }^{40}$ These political developments seemed to have curbed the radical critique of the state by Muslim intellectuals. In the process, most of the intellectuals I have analyzed adopted an alternative discourse which emphasized the merits of liberal democracy and the rule of law; whereas some of them criticized their former comrades in Yeni Zemin for their departure from the erstwhile critical attitude in the magazine.

After the 1997 military memorandum, the state's crackdown on Islamic segments of society resulted in dissension among RP-FP politicians, and the foundation of the AKP by the moderate wing. ${ }^{41}$ Moreover, in the context of the February 28 process, the majority of Islamic communities, which had 
hitherto abstained from cooperating with the RP and its former leader Necmettin Erbakan, supported the AKP. ${ }^{42}$ Within only a year after its foundation, the party won the 2002 general elections by a great margin and formed a single-party government. The AKP proclaimed itself a 'conservative democratic' party through a booklet penned by Yalçın Akdoğan, former assistant editor of Yeni Zemin, which emphasized democratic values, the rule of law, pluralism, respect for diversity, human rights, and more importantly adherence to secularism. ${ }^{43}$ The AKP's official position on democracy and the political system in Turkey enunciated by Akdoğan did not echo the radical critique of the state and democracy debates in Yeni Zemin. 'Fortifying the democratic regime,' he wrote, 'enables the peaceful coexistence of diversities within society, the reconciliation of the state with the nation and restoration of the worn-out system. ${ }^{44}$ Akdoğan defined democracy as a factor that was going to restore the system, instead of transforming it. In other words, the $\mathrm{AKP}$, in its initial years, did not call for reforming the political system, let alone changing it altogether as envisaged in Yeni Zemin.

The party's accommodationist discourse vis-à-vis the state establishment contradicted the critique of the system observed clearly in the 1990s especially when we remember that the Muslim intellectuals of Yeni Zemin sharply clashed with the Welfare Party on that front. ${ }^{45}$ This contradiction was a sign of the deeper division within Turkish Islamism in general and among the former Yeni Zemin authors in particular. Some of the intellectuals welcomed the transformation within the political Islamic movement and the new discourse of the AKP as the actualization of the Islamist demands for change. The former Yeni Zemin editor Mehmet Metiner, for instance, suggested that the February 28 process proved that the democratization of the Islamic movement in Turkey, advocated by himself and other Yeni Zemin authors since the early 1990s, is the only viable option of Islamic political movement in Turkey. He developed this position as the political counselor of the AKP's leader in designing the pro-democratic, pro-liberal and pro-EU discourse of the party. Metiner believed that the AKP had become a political platform with the potential and will to democratize the existing political system in Turkey. ${ }^{46}$

Muslim intellectuals who were enthusiastic for the new discourse of the AKP and the party's reforms were also the ones who moderated the radical tone of their critique in the 1990s. In the moderate Islamist discourse, instead of the antagonism between state and civil society and the calls for state's retreat from the civil societal domain, demands for a transparent state, the rule of law, and human rights multiplied. For example, Abdurrahman Dilipak stated that

the founding principle of the state must be that it is participatory, pluralistic, transparent, accountable, and governable. The state must follow the law in all 
circumstances. Justice, peace, freedom and human rights are the sine qua non conditions of the rule of law. ${ }^{47}$

Note that some of these values highlighted by Dilipak, in particular pluralism, participation, and justice, were part of the critique of the state in Yeni Zemin. Hence, the emphasis on democratic values in the Islamist rhetoric does not indicate an abrupt change; rather, the military memorandum prompted a reformulation of the existing Islamist critique of the state around the concepts of the rule of law, transparency and accountability. ${ }^{48}$

Along with the emphasis on the human rights and the rule of law, the moderate Islamist discourse in the aftermath of the February 28 highlighted the compatibility of Islam and democracy more patently and confidently. Yet, in a similar fashion to Akdoğan's remarks, Muslim intellectuals who adopted a moderate position refrained from presenting democratization as a process that would change the political system in Turkey altogether. In the context of the February 28 process, democracy became an instrument through which the Islamic segments of society could secure a place within the socio-political system in Turkey without state persecutios. This is most clear in the stress on pluralism in discussions of democracy by Mehmet Metiner, Yalçın Akdoğan, Ali Bulaç and other like-minded intellectuals, in addition to the deployment of the concepts of human rights and the rule of law in their discourse. Hence, state persecution of Islamic movements, religious communities and the visibility of religion, as in the case of the headscarf issue, had brought the instrumental importance of democracy into prominence. $^{49}$

While the significance of democracy in terms of the Islamist critique had changed, there was, however, continuity in the conception of democracy in Islamist discourse. Dissociating democracy from certain notions such as secularism and identifying it as a system of representation of the people's will were two characteristic tendencies in Yeni Zemin. In the aftermath of the February 28 process, similar arguments were reiterated by some former Yeni Zemin authors. For instance, departing from his earlier critical attitude towards democracy, Ali Bulaç suggested that 'democracy emerges as a political technique, a regime of government and it does not have any meaning beyond this political framework. ${ }^{50}$ Although Bulaç's main concern was to respond to the laicist outburst against the Islamic segments right after the military intervention, in contradiction to the moderate Islamist emphasis on pluralism and human rights, his remark identifies democracy with a set of procedures to determine political decision-makers.

In this period, moderate Islamist discourse featured the fray between the elected and appointed officials, which seemed to replace the centrality of antagonistic conceptions of state and civil society. Muslim intellectuals who shared a similar notion of democracy with Ali Bulaç often highlighted the legitimacy of 
elected representatives against appointed bureaucrats. According to Davut Dursun, 'appointed officials do not qualify to represent the people and institutions formed by the representative officials'; thus, the transfer of authority from the representative to the appointed officials results in 'restriction of the domain of politics. ${ }^{51}$ Dursun defined politics as a practice that is to be undertaken by the elected representatives of the people. This interpretation echoes with the notion of democracy Ergün Yıldırım espoused in Yeni Zemin. However, unlike the Ylldırım, Dursun's remark does not invoke any specific religious or political identity of the people. The absence of references to the supposedly Muslim identity of the people and of calls for changing the political system in accordance with that identity is one of the salient examples of moderation in the Islamist critique after the February 28.

Despite its prevalence within Turkish Islamism and among the former Yeni Zemin authors in particular, moderation was only one of the attitudes taken by Islamists in the context of the February 28 process. Moreover, the AKP, with its accommodationist strategy in politics, was far from being the political platform that united Turkish Islamists in this context. As stated, Muslim intellectuals who adopted a moderate discourse in the early 2000s supported the AKP as they saw the party representing a path they envisaged since the 1990s. Despite excitement for the party among intellectuals such as Metiner, Dursun, Bulaç and Yıldırım, however, none of them appeared to be truly party intellectuals or ideologues. ${ }^{52}$ On the other hand, the AKP's renunciation of its Islamist past, its cooperation with conservative and liberal sectors, its rhetorical adherence to secularism, and its pro-Western stance led many Islamists to remain distant to the party or to turn away. Apart from radical Islamist circles such as Haksöz and İktibas, which had always been critical of Islamist discourse on democracy and civil society, some Turkish Islamists criticized the acquiescence of their former comrades to the existing political system in Turkey and the AKP's effort to reconcile Muslim identity with secularism and liberalism.

Concerns of the Islamist critics toward moderate Islam and the AKP were also shared by some former Yeni Zemin authors. Although they were not particularly against liberal democratic notions or the party, intellectuals such as Rasim Özdenören and Ümit Aktaş raised their criticisms to the acquiescent attitude among other Muslim intellectuals regarding democracy. Remember that Özdenören dissented from other Yeni Zemin authors on democracy's relevance in Islamic contexts, and he maintained his criticism to the efforts to reconcile Islam and democracy for, he thought, these efforts aimed to earn the sympathy of those who do not hold Islam in high regard. ${ }^{53}$ After February 28, Özdenören re-affirmed that the pro-democratic voices within the Islamic movement resulted from the popularity of liberal democratic discourse and its hegemony in the post-Cold War context. Perhaps a more vocal critique of moderation in Islamist discourse came from Ümit Aktaş, who was a 
strong-minded supporter of democratization demands in Yeni Zemin. Castigating the moderate Islamists' acquiescence to democracy, Aktaş said:

[i]t is true that democracy is a step forward towards the hope for liberation of our country; but, after all that has been said about it, could we agree that democracy is the final step? Shall we ignore the fact that democracy created deadlocks; representation produces new relations of tutelage; it [democracy] eventually bestows rightfulness to the strong and leaves minorities unprotected. ${ }^{54}$

Aktaş expressed his disappointment with the evasion of a critical attitude among Islamist circles in debates on democracy as well as their concept of democracy which stressed the significance of representation. For him, demands for democratization turned into dissimulation (takiyye) as Muslim intellectuals abuse the instrumental value of democracy by leaving their critical stance towards the concept aside.

As these examples have demonstrated, the post-28 February 1997 transformation of Turkish Islamism contains many complexities and contradictions. The most dominant tendency within Turkish Islamism after the military intervention was moderation in the critique of the state. However, moderation was only one of the responses, which created controversies and discontent among other Muslim intellectuals. The moderation in the Islamist discourse of the early 2000s, which accompanied the AKP's accommodationist position, touted democracy as a shield against the state's oppressive measures toward Islamic segments. However, I have characterized the dominant post-February 28 discourse as moderate not because Islamists incorporated democracy and other liberal democratic concepts into their discourse. Rather, the concept of moderation I employ here refers to the process whereby Islamists toned down their critique of the state. This process was different from Turkish Islamists' shift to post-Islamism in the 1990s in the sense that Asef Bayat uses. While Ümit Aktaş, for instance, could be named as a typical post-Islamist intellectual, he strictly opposed the moderation of Islamist discourse and remained critical of other Muslim intellectuals. Conflating post-Islamism with moderate Islam, most studies in the literature miss these complexities and the dynamics of transformation within Turkish Islamism during and after the February 28 process.

\section{The AKP state? Demise of the Islamist critique}

During the AKP's second and third terms in office, the tension between the Islamist critique of the state and the AKP's political position was mostly resolved as the AKP took root in the state establishment through a series of electoral victories. In this period, most former Yeni Zemin authors abandoned their critical stance towards the state because the AKP became Turkey's 
dominant political actor following a series of events that ended the political influence of the Kemalist military and civil bureaucracy. The Ergenekon case that started in 2008 was followed by subsequent trials and was the first major incident that resulted in the Kemalists' elimination from the positions of power. ${ }^{55}$ While the AKP gained the upper hand vis-à-vis the military after these trials started, the constitutional referendum in 2010 confirmed the superior position of the civilian government against the military and allowed the AKP government to redesign the judiciary. ${ }^{56}$ It is no coincidence that the party's shift to an increasingly authoritarian discourse and a religious conservative agenda took place after these developments. This shift has gradually alienated liberal intellectuals who had provided intellectual support to the party against the Kemalists since $2002 .^{57}$ The final step in divergence between the liberals and the AKP was the Gezi Park protests in the summer of 2013. ${ }^{58}$

Meanwhile, the 2008 global financial crisis had a dramatic impact on both Muslim intellectuals' approaches to liberal democracy and the AKP's foreign policy. The financial crisis shook the hegemony of the liberal democratic rhetoric which had been dominant since the end of the Cold War. ${ }^{59}$ Remembering that this was one of the intellectual sources of Muslim intellectuals' demands for democratization in the 1990s, another pillar of Islamist discourse on democracy has waned. Moreover, although it is disputable to argue that the AKP's departure from its earlier pro-EU and pro-Western stance was an outcome of the financial crisis, the latter seemed to facilitate the so-called 'shift of axis' in foreign policy. This departure, however, did not seem to create any discontent among the moderate Muslim intellectuals of the postFebruary 28 period who once celebrated the party's reforms in line with EU harmonization. Among other Islamist circles with anti-Western sentiments, on the other hand, the 'shift of axis' away from the West boosted the legitimacy of the party. The final touch to the new dynamics of the relationship between different factions within Turkish Islamism and the AKP was the dramatic breakdown of the AKP's partnership with the Gülen network after 2013. ${ }^{60}$ For some Islamist circles, the Gülen movement is a stooge for American policies on Islam and promotes a Western-friendly moderate $[\imath \mathrm{llmll}]$ Islam. The AKP's split with it was celebrated by religious communities and Islamist groups which have been hostile to the movement.

As a result of these changes in Turkey's political landscape, many Muslim intellectuals began designating the AKP as Turkey's foremost progressive and innovative political actor. Whereas the party is treated as a revolutionary force by intellectuals, its political rivals are seen as the remnants of the 'old Turkey' that strove to protect the status quo. Nevertheless, the AKP's consolidation of power has had a dual impact on Muslim intellectuals. ${ }^{61}$ In contrast to those who adjusted their discourse from a critical one to a more conservative/ nationalist and compliant one, intellectuals such as Ümit Aktaş, Altan Tan and Ali Bulaç seem persistent in their critique of the existing socio-political 
system and remain distant from both the AKP and their former associates from Yeni Zemin. ${ }^{62}$

Changes and continuities in Muslim intellectuals' discourses since 2008 are closely linked to their relationship, official or unofficial, with the AKP. The general attitude of the pro-AKP intellectuals is to single out the AKP as a revolutionary agent standing against the guardians of the status quo which include virtually all the other political organizations, including the political parties in the parliament. For Rasim Özdenören,

[t] he main point of conflict between the status quo supporters (conservatives [tutucular]) and revolutionists (the AK Party) is the antagonism between those who want to preserve the principles of the established system as in the 1920 s and 1930s and those who want to modify it in accordance with the changing conditions. ${ }^{63}$

Özdenören refers to the incompatibility between, one the one hand, the statist, nationalist and modernist state establishment founded in the early years of the Republic, and, on the other, the global political landscape as well as Turkey's shifting social structure since the 1980s. In so doing, he praises AKP policies by leaning on the themes Muslim intellectuals utilized in the 1990s in their challenge to the state establishment.

Despite the enthusiasm of AKP-oriented Muslim intellectuals after 2008, a few others severely criticized the party's ideological stance and its inability to realize the Islamist ideals presented in Yeni Zemin. Arguing that the dynamism of the Islamic segments of society brought the AKP to power, Ümit Aktaş states that the party is trying to 'create a conservative movement out of a revolutionary, pro-change and libertarian [Islamist] movement [by] integrating it to the status quo in a way to ensure the duration of its own vested power. ${ }^{64}$ Aktaş's remarks suggest that the AKP operates within the limits of the existing political system - of which he remains critical. Ali Bulaç, agreeing with Aktaş's discontent with the AKP, is concerned that Islam and Islamism might be held accountable for all the faults of the AKP, despite the party giving up an Islamic political identity and promoting itself as a conservative party. ${ }^{65}$ The critics of the AKP emphasize that the party contradicts the worldview and expectations of the social segments it claims to be representing due to its willingness to use the state apparatuses that have long been targets of Islamists' criticism.

In contrast to these criticisms, Muslim intellectuals close to the AKP seem to identify the party's position with the aspirations and interests of the Islamic segments of society. Since 2008 the discourse of most former Yeni Zemin authors has ceased to advocate for the autonomy of civil society against the state, as the Islamic segments of society enjoy state recognition and are integrated into the political system in various ways. ${ }^{66} \mathrm{~A}$ striking example is the AKP-oriented intellectuals' silence on the issue of state intervention into 
the domain of religion. In the second and the third terms of the AKP in office, the DİB has assumed a critical role in AKP's policies towards Islamization of society and to combat the Gülen network and its version of Islam. When, during its campaign for 2015 general elections, the HDP and especially former Yeni Zemin author Altan Tan brought the status of the Directorate of Religious Affairs into question, many intellectuals who had advocated for its abolishment in Yeni Zemin said nothing. Although intellectuals' support for the AKP in its battle with Gülenists might lead them to prefer a state-promoted Islam over a Gülenist version, similar silences in almost all the issues that were once raised by Yeni Zemin authors concerning support for a minimal state and a larger civil society indicate that the aversion to discuss the status of the DİB stems from their compliance with the AKP and the state apparatuses that are controlled by the party. Thus, as the AKP takes root in the state establishment in Turkey, Muslim intellectuals' erstwhile discourse based on a severe critique of the very notion of the state has faded away.

The pro-AKP intellectuals' articulation of democracy and its central values have evolved in step with the party's political struggles. Their stance vis-à-vis the AKP and the other parties and their critical/judgmental attitude towards organizations at odds with the government undermine the value of political pluralism in their discourses. Hence, pluralism, a key concept in Yeni Zemin and in the post-memorandum period, has lost its prominence among Muslim intellectuals. Similarly, stress on human rights, the rule of law and the accountability have been replaced by a stronger emphasis on the antagonism between the 'elected' and the 'appointed.' Mehmet Metiner's reaction to a polemic between the president of the Constitutional Court and then Prime Minister Recep Tayyip Erdoğan in April 2014 is a case in point. Metiner first asks:

[d]o the members of the Constitutional Court want to do politics? Or do they want to create a power domain [iktidar alani] for themselves by taking position in political quarrels? Then, as the PM says, they remove their frocks and appear as they are ... You cannot do politics in that frock ... . ${ }^{67}$

He ends the article with a more profound critique of the Constitutional Court based on his conviction that the Court was trying to maintain a tutelary role over the 'real determining power' in a democratic country, that is, the elected civil authority. ${ }^{68}$ Seeing the AKP as the civil authority, Metiner points to the fact that the party is the true representative of the popular will and therefore the only legitimate arbiter in politics. As such, the contradiction between Muslim intellectuals' liberal discourse and their emphasis on the supremacy of popular will finally resolved in favor of the latter.

The reactions to the Gezi Park protests in the summer of 2013 demonstrate very well the intellectuals' new articulation of democracy. In the weeks after 
the first protests took place, most Muslim intellectuals accused the protest movement of being a coup attempt against the AKP government. According to Abdurrahman Dilipak, the organizers of protests were 'a cadre that gave up hope in the ballot box and is stalemated with the February 28 [memorandum] trial ... The American ambassador was involved in it too. So was the daily Le Monde and Germany. And so were their inner extensions of course. ${ }^{69}$ Dilipak enjoins the

community of Gezi Park [to found] a party since all of Turkey allegedly supports them. There are rightists, leftists, religionists, all of them. Let's see how much vote they will get. Let them write down their demands from the government to their party manifesto. Undoubtedly, everything is not about the ballot box; but what a democracy without ballot box means should be taken into account too. ${ }^{70}$

Dilipak's comment on Gezi Park protests indicates that the 'ballot box' and 'popular will' are prioritized over other values that the intellectuals used to associate with democracy such as participation, civil society and pluralism. These liberal democratic values have lost their significance for the Islamist discourse during the second and third terms of the AKP.

Islamists' shifting conceptions of democracy may reflect an instrumental embrace of democracy in order to gain recognition for Islamic identity and consolidate the political rights of the Islamic segments of society. Nevertheless, their surreptitious undermining of liberal democracy has not been accompanied by articulation of alternative political projects, neither as a counter-project to the existing system nor as an autonomously defined, ideal-type democracy. Although the global financial crisis of 2008 was a significant event in this discursive shift, as it shattered the image of liberalism among Muslim intellectuals, it did not prompt any debate over Islamic political models among former Yeni Zemin authors. Instead, those who are close to the AKP reiterate the party's discourse on re-creating a 'Greater Turkey ${ }^{71}$-which still reflects pan-Islamist ideals but with a strong nationalist twist.

\section{Conclusion}

Analysis of Muslim intellectuals' writings from the 1990s to 2010s demonstrates that the state in the Islamists' conception has transformed from an obstacle for Islamist ideals into a means for realizing them. First, Islamist political thought of the mid-1990s, observed through a close reading of Yeni Zemin, offered radical opposition to the state establishment in Turkey by invoking the ideals of democracy, civil society and pluralism. Second, a study of influential Muslim intellectuals' writings following the 1997 military memorandum indicates continuity in the Islamist critique of the state, albeit 
in a moderate way. The moderation had already triggered the first bifurcation among Muslim intellectuals in the aftermath of the memorandum. Finally, writings of the same intellectuals in the post-2008 period, in which the AKP consolidated its political power, reveal a state-centric mentality on the part of intellectuals close to the AKP who stopped championing the ideals of civil society and pluralism. Yet, this transformation crystallized the split among Muslim intellectuals that had already started after February 28. While some of them established close ties with the AKP, others kept their distance from the party and continued their critiques. However, it is important to note that the party's control over resources and media marginalizes the voices of Muslim intellectuals who remained critical of the AKP as well as the political system.

In order to account for the transformation of the Islamist critique of the state, this paper scrutinized the impact of the February 28 military memorandum and of the AKP's post-2008 triumph in Turkish politics. The impact of these major, recent political developments on Turkish Islamist political thought is often overlooked in the existing literature due mostly to inattention to the complexities of Islamism in Turkey. Apart from the frequently noted observation that Islamism - both as a social movement and a political ideology - is not monolithic, this paper shows that even the same actors may easily and dramatically alter their discourse depending on the social and political context. While, for example, democracy was an instrument of Muslim opposition to the state in Yeni Zemin, it became a means for Islamic segments to be integrated into the political system in the aftermath of the February 28. Finally, after 2008, Muslim intellectuals such as Metiner and Dilipak employed the ideal of democracy mostly to solidify the position of the AKP within the state establishment, whereas Aktaş and Tan used democracy to criticize the ruling AKP and its wielding of power.

In other words, not only have Muslim intellectuals formulated their conception of the state in different ways but they also loaded the same concepts with different interpretations under different socio-political conditions since the 1990s. The contextual analysis of Muslim intellectuals' writings in this paper demonstrated that it is mostly their affiliation to Islamic segments of the society and the position of these segments within the general socio-political context that accounts for the change in Islamist political thought. As the AKP emerged as a powerful political organization, the majority of Muslim intellectuals turned their affiliation to Islamic segments into affiliation to the AKP. On the other hand, there are still Muslim intellectuals who oppose identifying Turkish Islamism with the AKP, as in the cases of Bulaç and Aktaş. Yet, the pro-AKP attitude seems strong and pervasive accompanying the AKP's political dominance which overshadows the diversity within Turkish Islamism revealed in this paper. 


\section{Notes}

1. See for instance, Roy, Failure of Political Islam; Göle, "Authoritarian Secularism"; Eickelman and Piscatori, Muslim Politics; Bayat, "Post-Islamism"; and White, "The End of Islamism?".

2. Schwedler, Faith in Moderation, 11-12, and Wickham, "Path to Moderation," 206.

3. See for instance, Salame, Democracy Without Democrats?.

4. See, for instance, Turam, Islam and the State; Hale and Özbudun, Islamism, Democracy and Liberalism; and Dağı, "Post-Islamism à la Turca".

5. Tuğal, The Turkish Model, 4-10.

6. Hamid, Temptations of Power, 47.

7. Bayat, "Post-Islamism at Large," 27.

8. See Guida, "The New Islamists".

9. See Taşkın, "Hegemonizing Conservative Democracy".

10. Michelangelo Guida has published another article which discusses reflections of five Islamist columnists on the Gezi Park Protests and the 15 July 2016 coup attempt. Although the period that article covers is very limited, Guida admirably shows the complexity within Turkish Islamism and comments on the possible causes of diversity in terms of the reception of these events among Islamist columnists some of whom are subject to scrutiny in this paper too. See, Guida, "Negotiating Values."

11. See Yenigün, "The New Antinomies".

12. Despite its frequent use, what or who is actually referred to by the term 'Islamic segments' is not always clear. Ayşe Buğra includes under the umbrella of the constituencies of political Islam 'the newly emerging entrepreneurs [and] other segments of the middle class which include Islamic intellectuals and professionals, as well as the marginalized masses largely consisting of new immigrants in urban centres'. See Buğra, "Labour, Capital, and Religion," 189. Perhaps, the most significant social groups that must be incorporated into this definition are religious orders.

13. Here, I use the term 'imagined' in a similar sense that Benedict Anderson defines nationalism. In so doing, I see the attachment to the Islamic segments of society as a variant of nationalism.

14. The magazine was dissolved itself after publishing its 17th issue in July 1994 . There is no clear explanation as to why it was dissolved. Yet, such closures were very common among Islamist political magazines in the 1990s.

15. Nurcu is used to refer to the follower of Said Nursi (1877-1960), an important Islamic scholar in the late Ottoman and early Republican periods. The impact of the foundation's ideological orientation can be observed in recurrent themes and discussions in the magazine. The Kurdish question was one of the most central themes in Yeni Zemin which often appeared side by side with Islamist demands. For the Kurdish-Islamic identity of the magazine see Yavuz, Islamic Political Identity, 176.

16. Metiner began publishing several other popular Islamic magazines and books in the 1980s. He first joined the Kurdish nationalist People's Democracy Party (Halkın Demokrasi Partisi, HADEP) in 2000, and then joined the AKP and was elected to the Turkish parliament with the AKP in 2011 and 2015.

17. Özçetin, "Making of New Islamism," 220.

18. Tan joined the Felicity Party (Saadet Partisi, SP) before the June 2018 snap elections. Yet, he couldn't manage to keep his seat in the Parliament. The SP is an 
Islamist opposition party founded simultaneously with the AKP by the conservative wing of Milli Görüş in 2001.

19. Bulaç was released from prison after two years in May 2018 pending his trial.

20. Bora, Türk Să̆ının Üç Hali, 127.

21. Mardin, "Turkish Islamic Exceptionalism," 147.

22. Tuğal, Passive Revolution, 149, 277, and Yenigün, "The New Antinomies," 230.

23. Íkinci cumhuriyetçiler, or second republicans refers to a group of liberal intellectuals who challenge the Kemalist principles dominant in the political system of Turkey and argue for democratization of the state and liberalization of politics and economy. See Ersoy and Üstüner, "Liberal intellectuals' Narration," 409.

24. Aytürk, "Post-post Kemalizm," 36-37.

25. Aktaş, "Devlet; ama nereye kadar?," 19-20.

26. Dursun, "Türkiye'de değișenler," 22-23.

27. Founded in 1983, the RP was one of the Milli Görüş parties lead by Necmettin Erbakan (1926-2011). The RP rose its popularity among the Anatolian middle classes, the urban poor and lower-middle classes in the metropolitans especially in the early 1990s. The party captured significant municipalities including the capital Ankara and Istanbul in the 1994 local elections. The following year, it won the 1995 general elections and came to power as the leading coalition partner. However, soon after the National Security Council meeting on 28 February 1997, Erbakan resigned and the coalition broke up. As will be discussed in the next section, the RP was closed down by the Constitutional Court in January 1998 and imposed ban on political activities by party leaders including Erbakan and Recep Tayyip Erdoğan, then mayor of İstanbul. For a detailed analysis of the RP, see Yavuz, "Political Islam."

28. Metiner, "Siyasette yeni arayışlar," 24-25.

29. Dilipak, "Türkiye'de laiklik olmadı," 17.

30. "Dinin özgürleşme talebi," 7-8. It can be surmised that this article reflects the editorial line of the magazine.

31. Yavuz, Islamic Political Identity, 69-70.

32. Norton, "Introduction," 22.

33. Similar interpretations of the 'center-periphery' approach propounded by Şerif Mardin in the early 1970s and became the prevalent framework to explain Turkish politics in the 1990s were highly popular among Yeni Zemin authors. These versions of center-periphery reflect their identitarian approach. See Dursun, “Türkiye’de değișenler”; Metiner, “Toplum merkezli, özgürlükçü”; Tan, "Türkiye yol ayrımında"; "Müslümanlar laiklik kıskacında”; and Dursun, "Mahalli yönetimler ve seçimler."

34. Yeni Zemin evidently received negative responses from the readership. The editor Metiner felt necessary to justify the magazine's position regarding democracy as well as other concepts associated with Western liberal thought in the editorials of the first few volumes. For instance, the editorial of the fifth volume asserted that Yeni Zemin was certainly based on an Islamic worldview:

That we speak in others' [read "non-Islamic"] language does not mean that we surrendered.... We too know that it is not possible to build a new world with 'borrowed concepts' [such as democracy and civil society]. However, we believe that we should not turn our back to 
these concepts which are popularly used to conceive and express socialpolitical issues, just because they are 'foreign'.

See "Yeni Zemin'den".

35. See Özdenören, "Demokrasi egemen sınıfın lehinedir," and Bulaç, "Demokrasi içinde politikaya katılmak."

36. Mert, "Tarihsel Bir Bakış," 418.

37. Yıldırım, "Türkiye siyasal geleneğinde demokrasi," 17.

38. Bayat, "Post-Islamism at Large," 10.

39. Some notable magazines that Muslim intellectuals in Yeni Zemin contributed to in the 1990s were İlenim, Bilgi ve Hikmet, Değişim and Sözleşme.

40. Hale and Özbudun, Islamism, Democracy and Liberalism, 244.

41. For different accounts of this development, see White, "The End of Islamism?"; Turam, Islam and the State; Hale and Özbudun, Islamism, Democracy and Liberalism; Dağı, "Post-Islamism à la Turca"; Atacan, "Explaining Religious Politics"; Tuğal, Passive Revolution; and Tezcür, Muslim Reformers.

42. Some religious communities with relatively large bases had been supporting the center-right parties instead of Erbakan-led Islamist parties. Most prominent among them was the Gülen community. Under state's repression in the aftermath of the February 28, these communities supported the reformist wing of the RP and, in a way, they became part of the social coalition that made up the AKP. See Yavuz, Islamic Political Identity, 258.

43. Hale and Özbudun, Islamism, Democracy and Liberalism, 20. For the booklet, see Akdoğan, Muhafazakar Demokrasi.

44. Akdoğan, Muhafazakar Demokrasi, 82 .

45. For more details of the AKP's accommodationist strategy see Atacan, "Politics at Crossroads," 194, and White, "The End of Islamism?," 88.

46. Metiner, Yemyeşil Şeriat Bembeyaz Demokrasi, 550.

47. Dilipak and Yurdatapan, Ortak Payda, 66.

48. In fact, we can observe reflections of this trend among the popular sectors of the Islamic movement from the 1990s onwards. As democratic values and the rhetoric of human rights have reigned supreme following the end of the Cold War, Islamic demands such as freedom to wear the headscarf have been presented in the framework of freedom of faith and religion, civil liberties and/ or human rights. See Mert, "Tarihsel Bir Bakış," 411-9. Note that there was no consensus on presenting the hijab or other elements of Islam in a liberal framework. The dominant opinion among Muslim intellectuals was to convince people that the hijab is mandatory for Muslims. On the other hand, performing religious duties in accordance with one's faith is considered within the realm of civil rights and liberties. For example, see Bulaç, "Başörtüsü," 33-38.

49. See, for instance, Metiner, Yemyeşil Şeriat Bembeyaz Demokrasi, 458. A similar pragmatic shift can be observed in Islamists' stance towards the EU in this period. There was a conviction that the EU harmonization process was the only possible way to end the Kemalist bureaucratic tutelage and the rigid implementation of secularism which had led to the political, economic and social exclusion of the Islamic segments of the society. As the EU became instrumental in channeling the demands of Muslim intellectuals for change, their quest for an Islamic alternative to Western modernity was largely replaced by the necessity of reforms for Turkey's harmonization with the EU. See Metiner, Cennet Düşü, 56-57; Bulaç, Avrupa Birliği ve Türkiye; and Akdoğan, Kırk Yıllık Düş. 
50. Bulaç, "Demokrasi."

51. Dursun, "Siyasetin daralması."

52. Although most former Yeni Zemin authors seemed to align themselves with the AKP, they did not refrain from criticizing the party and its leader, Recep Tayyip Erdoğan. For example, Ali Bulaç was among the Islamist opposition to the AKP government's support for Turkey's involvement in American invasion of Iraq in 2003. Another example is Mehmet Metiner's reaction against Erdoğan's outburst in the 'adultery debate' in 2004. See Metiner, Cennet Düşü, 59.

53. Özdenören, "Bir Demokrasi Türü," 32.

54. Aktaş, "Ütopya'nın Çöküşü,” 122.

55. In 2008, an assumed clandestine organization, Ergenekon, was accused of establishing networks in the military, judiciary, bureaucracy, academia, media and civil society to plot against the government. A series of indictments were issued against a number of high profile military officers, bureaucrats, journalists and NGO leaders in what is known as the 'Ergenekon trials'. See Kaya, "The Ergenekon Case," 152. The process was followed by trials against an alleged coup attempt known as Balyoz (sledgehammer) and then by an investigation of the February 28 military memorandum. As of October 2016, most of the charges have been dropped in those trials, some of the military officers who were accused of being involved in coup attempts were released and some officers have returned to duty. See Hurriyet, "Mağdur oldular, cezaevinde yattılar, beraat ettiler ve göreve dönüyorlar," July 22, 2016, at http://www.hurriyet.com.tr/magdur-oldular-cezaevinde-yattilar-beraat-ettiler-ve-yeniden-atandilar-40163342. Accessed on October 24, 2016.

56. Müftüler-Baç and Keyman, "Dominant-Party Politics," 85.

57. Ersoy and Üstüner, "Liberal Intellectuals' Narration," 416-8.

58. In accordance with the government's project for renovation of Taksim square, the City Council of Istanbul decided to destroy Gezi Park nearby the square and re-build an Ottoman military barrack. Following the decision, a group of environmental activists pitch their tents in the park to resist the destruction. The violent attack of security forces to remove the protesters from the park to continue the construction process on 28 May2013 severely backlashed. Thousands of people rushed into the square to repel the security forces and occupy the park. The process escalated in public protests all around the country. Targeting mainly the government and its authoritarian tendencies, the protests lasted until the mid-June in Istanbul as well as in other major cities.

59. In making this observation, I rely on the writings of the intellectuals I analyze in this paper. For examples of repercussions of the 2008 crisis among Muslim intellectuals, see Dilipak, “Ah Fukuyama ah!”; Bulaç, “'Çok hukuklu' olmak”; and Dilipak, "Evet eksen kayması ...." Recent studies on AKP's authoritarian shift excessively focus on domestic politics to account for it. I believe a thorough analysis of the impact of the 2008 global financial crisis on AKP and Islamism is still needed.

60. The tension between Gülen network and the AKP is presumably dated back to Turkey's conflict with Israel after Israeli soldiers attacked on Gaza flotilla in 2010, known as 'Mavi Marmara' incident. The tension became an open strife after the government corruption scandal in late 2014. The AKP claimed that the investigations in 17 and 25 December 2014 were carried out by government and media figures in Gülen network in order to topple down the AKP 
government. The conflict came to its zenith after the coup attempt in 15 July 2016 and thousands of military and civil officers have been arrested.

61. For the AKP's hegemony in Turkish politics after its second term, see Özbudun, "AKP at the Crossroads"; Çınar, "Emerging Electoral Hegemony"; Yeşilada, "The Future of Erdoğan”; and Öniş, "Monopolising the Centre."

62. From the beginning, Bulaç had an ambivalent attitude towards the AKP. While he tried to keep himself as an independent intellectual who maintain a distance, his arguments were usually in tune with the position of the government. Although Bulaç never explicitly associated himself with the Gülen network, he has become increasingly critical of the AKP after the party begun a battle with Gülen and his followers in late 2013.

63. Özdenören, "Yenilikçilerle tutucuların savaşımı."

64. Aktaş, “Pasif devrim' mi,” 86.

65. Bulaç, "Özeleştiri."

66. For instance, Ayşe Buğra and Osman Savaşkan illustrates the rise of Islamicoriented business associations through cooperation with the AKP government while other associations have been marginalized both at macro and micro levels. See Buğra and Savaşkan, New Capitalism in Turkey.

67. Metiner, "Vesayet vesayettir işte!."

68. ibid.

69. Dilipak, "Mesele park meselesi değil."

70. Dilipak, "Şahin Alpay'dan.”

71. See for instance Özdenören, "Büyük devlete doğru."

\section{Acknowledgements}

This paper emerged out of my M.A. thesis written at Koc University under the supervision of Alexis Rappas and Cihan Tugal. I owe them a lot. I would like to thank Alev Cinar and Ilker Ayturk as well as the editor and the two anonymous reviewers of Turkish Studies for their comments and criticisms to the earlier drafts.

\section{Disclosure statement}

No potential conflict of interest was reported by the author.

\section{Notes on Contributor}

Talha Köseoğlu is currently a Ph.D. candidate in the Department of Political Science and Public Administration at Bilkent University and a research assistant in the Department of Political Science and Public Administration at Eskişehir Osmangazi University. He completed his M.A. degree in Comparative Studies in History and Society at Koç University. His research interests include comparative political theory, Islamic political thought, state-society relations, and political Islamic movements.

\section{ORCID}

Talha Köseoğlu (D) http://orcid.org/0000-0002-7292-0119 


\section{Bibliography}

Akdoğan, Yalçın. Ak Parti ve Muhafazakar Demokrasi. İstanbul: Alfa, 2004.

Akdoğan, Yalçın. Kırk Yıllık Düş: Avrupa Birliği'nin Siyasal Geleceği ve Türkiye. İstanbul: Alfa, 2004.

Aktaş, Ümit. “Devlet; ama nereye kadar?” Yeni Zemin 5 (1993): 19-20.

Aktaş, Ümit. “Ütopya'nın Çöküşü.” Birikim 139 (2000): 121-123.

Aktaş, Ümit. “Pasif devrim' mi, statükonun dönüşümü mü?” Birikim 283 (2012): 79-87. Atacan, Fulya. "Explaining Religious Politics at the Crossroad: AKP-SP." Turkish Studies 6, no. 2 (2005): 187-199.

Aytürk, İlker. "Post-post Kemalizm: Yeni Bir Paradigmayı Beklerken.” Birikim 319 (2015): 34-48.

Bayat, Asef. "The Coming of a Post-Islamist Society." Critique: Critical Middle East Studies 5, no. 9 (1996): 43-52.

Bayat, Asef. "Post-Islamism at Large." In Post-Islamism: The Changing Faces of Political Islam, edited by Asef Bayat, 3-32. New York: Oxford University Press, 2013.

Bora, Tanıl. Türk Sağının Üç Hali: Milliyetçilik, Muhafazakarlık, İslamcılık. İstanbul: Birikim, 1998.

Buğra, Ayşe. "Labour, Capital, and Religion: Harmony and Conflict among the Constituency of Political Islam in Turkey." Middle Eastern Studies 38, no. 2 (2002): 187-204.

Buğra, Ayşe, and Osman Savaşkan. New Capitalism in Turkey: The Relationship between Politics, Religion and Business. Cheltenham: Edward Elgar, 2014.

Bulaç, Ali. "Özeleştiri." Zaman, December 30, 2013.

Bulaç, Ali. “Demokrasi.” Zaman, April 26, 1998.

Bulaç, Ali. “'Çok hukuklu' olmak.” Zaman, July 13, 2009.

Bulaç, Ali. "Demokrasi içinde politikaya katılmak.” Yeni Zemin 6 (1993): 18-20.

Bulaç, Ali. Avrupa Birliği ve Türkiye. İstanbul: Eylül, 2000.

Bulaç, Ali. “Başörtüsü: Çözümler, Sorular, Yeni Perspektifler.” Umran 129 (2005): 33-38.

Çınar, Kürşat. "Local Determinants of an Emerging Electoral Hegemony: The Case of the Justice and Development Party (AKP) in Turkey." Democratization 23, no. 7 (2016): 1216-1235.

Dağı, İhsan. "Post-Islamism à la Turca." In Post-Islamism: The Changing Faces of Political Islam, edited by Asef Bayat, 71-108. New York: Oxford University Press, 2013.

Dilipak, Abdurrahman. “Şahin Alpay'dan evirip çevirmeden.” Yeni Akit, June 9, 2013.

Dilipak, Abdurrahman. “Mesele park meselesi değil, hâlâ anlamadınız mı?” Yeni Akit, June 7, 2013.

Dilipak, Abdurrahman. "Evet eksen kayması.” Yeni Akit, October 24, 2010.

Dilipak, Abdurrahman. "Ah Fukuyama ah!" Yeni Akit, August 21, 2008.

Dilipak, Abdurrahman. "Türkiye'de hiçbir zaman laiklik olmadı." Yeni Zemin 2 (1993): 17.

Dilipak, Abdurrahman, and Şanar Yurdatapan. Ortak Payda: Yeşil-Kırmızı, KırmızıYeşil Denemeler. Istanbul: İnkılap, 2004.

Dursun, Davut. "Siyasetin daralması ve bürokratik cumhuriyet." Yeni Şafak, June 21, 1999.

Dursun, Davut. “Türkiye'de değişenler ve değişmeye karşı direnenler.” Yeni Zemin 1 (1993): 22-23.

Dursun, Davut. "Mahalli yönetimler ve seçimler.” Yeni Zemin 14 (1994): 13-15. 
Eickelman, Dale, and James Piscatori. Muslim Politics. Princeton: Princeton University Press, 1996.

Ersoy, Duygu, and Fahriye Üstüner. "Liberal Intellectuals' Narration of the Justice and Development Party in Turkey.” Turkish Studies 17, no. 3 (2016): 406-428.

Göle, Nilüfer. "Authoritarian Secularism and Islamist Politics." In Civil Society in the Middle East, Vol. 2, edited by A. R. Norton, 17-43. Leiden: Brill, 1996.

Göle, Nilüfer. "Secularism and Islamism in Turkey: The Making of Elites and Counter-Elites.” Middle East Journal 51, no. 1 (1997): 46-58.

Guida, Michelangelo. “The New Islamists' Understanding of Democracy in Turkey: The Examples of Ali Bulaç and Hayreddin Karaman.” Turkish Studies 11, no. 3 (2010): 347-370.

Guida, Michelangelo. "Negotiating Values in the Islamist Press after 2013.” Middle East Critique 27, no. 2 (2018): 193-206.

Hale, William, and Ergun Özbudun. Islamism, Democracy and Liberalism in Turkey: The Case of the AKP. New York: Routledge, 2010.

Hamid, Shadi. Temptations of Power: Islamists and Illiberal Democracy in a New Middle East. New York: Oxford University Press, 2014.

Kaya, Serdar. "The Social Psychology of the Ergenekon Case: The Collapse of the Official Narrative in Turkey." Middle East Critique 21, no. 2 (2012): 145-156.

Mardin, Şerif. "Turkish Islamic Exceptionalism Yesterday and Today: Continuity, Rupture and Reconstruction in Operational Codes." Turkish Studies 6, no. 2 (2005): 145-165.

Mert, Nuray. “Türkiye İslamcılığına Tarihsel Bir Bakış.” In Modern Türkiye'de Siyasal Düşünce Vol. 6: İslamcılık, edited Yasin Aktay, 411-419. İstanbul: İletişim, 2006.

Metiner, Mehmet. “Vesayet vesayettir işte!” Aktüel, April 14, 2014. http://www.aktuel. com.tr/yazar/mehmetmetiner/2014/04/14/vesayetvesayetti775ri775ste.

Metiner, Mehmet. "Herşeyi yeniden düşünmenin vaktidir.” Yeni Zemin 5 (1993): 4.

Metiner, Mehmet. "Siyasette yeni arayışlar." Yeni Zemin 2 (1993): 24-25.

Metiner, Mehmet. “Toplum merkezli, özgürlükçü sivil bir anayasa.” Yeni Zemin 4 (1993): 4-5.

Metiner, Mehmet. İdeolojik Devletten Demokratik Devlete [From the Ideological State to the Democratic State]. İstanbul: Beyan Yayınları, 1999.

Metiner, Mehmet. Cennet Düşü [A Dream of Heaven]. İstanbul: Günizi, 2004.

Metiner, Mehmet. Yemyeşil Şeriat Bembeyaz Demokrasi [Grass-green Sharia, Snowwhite Democracy]. Istanbul: Doğan Kitap, 2004.

Müftüler-Baç, Meltem, and E. Fuat Keyman. “The Era of Dominant-Party Politics.” Journal of Democracy 23, no. 1 (2012): 85-99.

"Müslümanlar laiklik kiskacında.” Yeni Zemin 13 (1994): 10-15.

Norton, Augustus R. "Introduction.” In Civil Society in the Middle East, Vol. 1, edited by A. R. Norton, 1-25. Leiden: Brill, 1995.

Öniş, Ziya. "Monopolising the Centre: The AKP and the Uncertain Path of Turkish Democracy." The International Spectator 50, no. 2 (2015): 22-41.

Özbudun, Ergun. "AKP at the Crossroads: Erdoğan's Majoritarian Drift." South European Society and Politics 19, no. 2 (2014): 155-167.

Özçetin, Burak. "Making of New Islamism in Turkey: Transformation of the Islamist Discourse from Opposition to Compliance." PhD diss., Middle East Technical University, 2011.

Özdenören, Rasim. "Yenilikçilerle tutucuların savaşımı." Yeni Şafak, January 5, 2014.

Özdenören, Rasim. "Büyük devlete doğru adım adım ... ” Yeni Şafak, January 2, 2014.

Özdenören, Rasim. “Demokrasi egemen sınıfın lehinedir.” Yeni Zemin 6 (1993): 21. 
Özdenören, Rasim. “Bir Demokrasi Türü: Seçim Demokrasisi.” Umran 98 (2002): 30-35. Roy, Olivier. The Failure of Political Islam. Cambridge: Harvard University Press, 1994.

Salame, Ghassan. Democracy Without Democrats?: The Renewal of Politics in the Muslim World. London and New York: I.B. Tauris, 1994.

Schwedler, Jillian. Faith in Moderation: Islamist Parties in Jordan and Yemen. New York: Cambridge University Press, 2006.

Tan, Altan. “Ortadoğu Demokrasi ve İslam - II.” 2000'de Yeni Gündem, November 8, 2000.

Tan, Altan. “Türkiye yol ayrımında." Yeni Zemin 9 (1993): 28.

Taşkın, Yüksel. "Hegemonizing Conservative Democracy and the Problems of Democratization in Turkey: Conservatism without Democrats?" Turkish Studies 14, no. 2 (2013): 292-310.

Tezcür, G. Murat. Muslim Reformers in Iran and Turkey: Paradox of Moderation. Austin: University of Texas Press, 2010.

Tuğal, Cihan. Passive Revolution: Absorbing the Islamist Challenge to Capitalism. Stanford, CA: Stanford University Press, 2009.

Tuğal, Cihan. The Fall of the Turkish Model: How the Arab Uprisings Brought Down Islamic Liberalism. London: Verso, 2016.

Turam, Berna. Between Islam and the State: The Politics of Engagement. Stanford, CA: Stanford University Press, 2007.

“Türkiye'de baskı altındaki dinin özgürleşme talebi.” Yeni Zemin 2 (1993): 7-8.

White, Jenny. "The End of Islamism?: Turkey's Muslimhood Model.” In Remaking Muslim Politics, edited by R. W. Hefner, 87-111. Princeton: Princeton University Press, 2005.

Wickham, Carrie Rosefsky. "The Path to Moderation: Strategy and Learning in the Formation of Egypt's Wasat Party." Comparative Politics 36, no. 2 (2004): 205-228.

Yavuz, M. Hakan. "Political Islam and the Welfare (Refah) Party in Turkey." Comparative Politics 30, no. 1 (1997): 63-82.

Yavuz, M. Hakan. Islamic Political Identity in Turkey. New York: Oxford University Press, 2003.

"Yeni Zemin'den." Yeni Zemin 5 (1993): 1.

Yenigün, H. İbrahim. "The New Antinomies of Islamic Movement in the Post-Gezi Turkey: Islamism vs. Muslimism.” Turkish Studies 18, no. 2 (2017): 229-250.

Yeşilada, Birol. "The Future of Erdoğan and the AKP.” Turkish Studies 17, no. 1 (2016): 19-30.

Yıldırım, Ergün. “Türkiye siyasal geleneğinde Demokrasi.” Yeni Zemin 6 (1993): 17. 